\title{
METODE PEMBELAJARAN KELAS IBU HAMIL TERHADAP PENGETAHUAN DAN SIKAP IBU TENTANG PERAWATAN KEHAMILAN, PERSALINAN DAN NIFAS
}

\author{
Elman Fitriani1 ${ }^{1}$, Dewita Dewita2 ${ }^{*}$ \\ ${ }^{1}$ D-IV Kebidanan Poltekkes Kemenkes \\ 2Prodi Kebidanan Poltekkes Kemenkes Aceh \\ Email Korespondensi: dewita@poltekkesaceh.ac.id
}

\begin{abstract}
PREGNANCY MOTHER'S CLASS LEARNING METHODS ON KNOWLEDGE AND ATTITUDE OF MOTHERS ABOUT PREGNANCY, DELIVERY AND PUBLIC CARE
\end{abstract}

Background: Maternal Mortality Rate in the world is still high due to complications during pregnancy and childbirth. All cases of maternal death can still be prevented through good service arrangements. The problem of infant mortality in the world is also high in the neonatal period, which is caused by prematurity, birth asphyxia and neonatal sepsis. The application of the class for pregnant women is expected to increase the accessibility of pregnant women to quality maternal and child health services so that it can be an effort to reduce maternal and infant mortality.

Objective: To determine the effect of multimedia learning methods in pregnant women's classes on knowledge and attitudes of mothers about care during pregnancy, childbirth and postpartum in the working area of the Langsa Baro Health Center.

Methods: This study was a quasi-experimental with a pre-test and post-test design with two groups. the control group for the class of pregnant women used the conventional learning method, while the treatment group used the multimedia learning method. Each group was carried out pretest and posttest using a questionnaire to determine the knowledge and attitudes of mothers about genital care, childbirth and postpartum in pregnant women. The research was carried out from 7 to 25 May 2019. The research location was in the working area of the Langsa Baro Health Center, Langsa City. Class meetings for pregnant women are 3 times / week in a row. The research sample amounted to 34 pregnant women. The sampling technique is purposive sampling, which is the determination of the sample with certain considerations based on predetermined inclusion criteria. Inclusion criteria were third trimester pregnant women, primigravida, normal pregnancy, pregnant women who were in the working area of Langsa Baro Health Center and were willing to be respondents. The instrument used is a questionnaire. Data analysis is t-dependent test. This research has received approval from the Health Research Ethics Commission of the USU Faculty of Nursing with the number: 2275/V/SP/2019.

Results: The results showed that there was a significant difference in knowledge and attitudes of mothers before and after being given learning in the conventional learning group was $0.000 p<$, and the multimedia learning method group was 0.000 which means $p<$. So it means that there is an influence of the class learning method for pregnant women (multimedia) with the knowledge and attitudes of mothers about care for pregnancy, childbirth, and postpartum in pregnant women in the working area of the Langsa Baro Health Center.

Conclusion: The results showed that there was an influence of the learning method (multimedia) in the pregnant women's class on the knowledge and attitudes of mothers about pregnancy, childbirth and postpartum care in the work area of the Langsa Baro Health Center.

Suggestions For health services, they should be able to apply classes for pregnant women with multimedia learning methods.

Keywords: Knowledge, Attitude, Class of pregnant women

\begin{abstract}
ABSTRAK
Latar Belakang: Angka Kematian Ibu di dunia masih tinggi yang disebabkan karena komplikasi selama kehamilan dan persalinan. Semua kasus kematian ibu masih dapat dicegah melalui pengaturan pelayanan yang baik. Begitu masalah kematian bayi didunia juga tinggi pada masa neonatal, yang disebabkan karena lahir prematuritas, asfiksia lahir dan neonatal sepsis. Penerapan kelas ibu hamil diharapkan dapat meningkatkan aksesibilitas ibu hamil terhadap pelayanan kesehatan ibu dan anak yang berkualitas sehingga dapat menjadi salah satu upaya dalam penurunan kematian ibu dan bayi.
\end{abstract}




\section{Elman Fitriani, Dewita Dewita}

Tujuan: Untuk mengetahui pengaruh metode pembelajaran multimedia dalam kelas ibu hamil terhadap pengetahuan dan sikap ibu tentang perawatan selama kehamilan, persalinan dan nifas di wilayah kerja Puskesmas Langsa Baro. Metode: Penelitian ini adalah Quasi-exsperimental dengan rancangan pre test dan pos test with two group. kelompok kontrol kelas ibu hamil menggunakan metode pembelajaran konversional, sedangkan kelompok perlakuan menggunkan metode pembelajarn multimedia. Setiap kelompok dilakukan pretest dan posttes menggunakan kuesioner untuk mengetahu pengetahuan dan sikap ibu tentang perawatan kelamilan, persalinan dan nifas pada ibu hamil. Penelitian dilaksanakan pada tanggal 7 sampai 25 Mei 2019. Lokasi penelitian dilakukan di wilayah kerja Puskesmas Langsa Baro Kota Langsa. Pertemuan kelas ibu hamil sebanyak 3 kali/ minggu secara berturut-turut. Sampel penelitian berjumlah 34 ibu hamil. Teknik pengambilan sampel yaitu purposive sampling, yaitu penentuan sampel dengan pertimbangan tertentu berdasarkan kriteria inklusi yang telah ditentukan. Kriteria inklusi adalah ibu hamil trimester III, primigravida, kehamilan normal, ibu hamil yang berada di wilayah kerja Puskesmas Langsa Baro dan bersedia menjadi responden. Instrumen yang digunakan berupa kuesioner. Analisa data yaitu uji $t$-dependent. Penelitian ini sudah mendapatkan persetujuan dari komisi etik penelitian Kesehatan Fakultas Keperawatan USU dengan nomor: 2275/V/SP/2019.

Hasil: Hasil penelitian ada perbedaan signifikan pengetahuan dan sikap ibu sebelum dan sesudah diberikan pembelajaran pada kelompok pembelajaran konvensional adalah $0,000 p<a$, dan kelompok metode pembelajaran multimedia adalah 0,000 yang berarti $p<a$. Maka artinya ada pengaruh metode pembelajaran kelas ibu hamil (multimedia) dengan pengetahuan dan sikap ibu tentang perawatan kehamilan, persalinan, nifas pada ibu hamil di wilayah kerja Puskesmas Langsa Baro.

Kesimpulan: Hasil penelitian menunjukkan adanya pengaruh metode pembelajaran (multimedia) kelas ibu hamil terhadap pengetahuan dan sikap ibu tentang perawatan kehamilan, persalinan dan nifas di wialayah kerja Puskesmas Langsa Baro.

Saran Bagi pelayanan kesehatan hendak nya dapat menerapkan kelas ibu hamil dengan metode pembelajaran multimedia.

Kata Kunci : Pengetahuan, Sikap, Kelas Ibu hamil

\section{PENDAHULUAN}

Keberhasilan pembangunan pada sektor kesehatan ditentukan berdasarkan indikator Angka Kematian Ibu (AKI) dan Angka Kematian Bayi (AKB). Hal ini juga menggambarkan kualitas ibu dan anak di Indonesia. AKI adalah jumlah kematian ibu selama masa kehamilan, persalinan dan nifas yang disebabkan oleh kehamilan, persalinan, dan nifas atau pengelolaannya tetapi bukan karena sebab-sebab lain dan lain-lain di setiap 100.000 kelahiran hidup (Kemenkes R.I, 2019). AKI di dunia diperkirakan sebanyak 216 kematian ibu per 100.000 kelahiran bayi hidup yang terjadi karena komplikasi kehamilan dan persalinan. Hampir semua kematian ini terjadi akibat faktor yang sebenarnya dapat dicegah melalui pengaturan pelayanan yang baik. Sedangkan untuk AKB di dunia diperkirakan sebanyak 19 per 1000 hidup kelahiran pada masa neonatal dengan penyebab utama prematuritas, komplikasi persalinan (asfiksia lahir) dan neonatal sepsis (World Health Organization, 2017).

Data dari profil kesehatan Indonesia (2018) dapat dilihat AKI di Indonesia berkisar pada angka 305 menyatakan kematian ibu per 100.000 kelahiran hidup dan AKB sendiri sebanyak 22,23 kematian bayi per 1.000 kelahiran hidup. Cakupan ibu hamil yang memperoleh pelayanan antenatal telah meningkat dari $85,56 \%$ pada tahun 2010 menjadi $87,3 \%$ pada tahun 2016. Cakupun persalinan yang ditolong tenaga kesehatan juga meningkat dari $79,0 \%$ pada tahun 2010 menjadi $86,9 \%$ pada tahun 2016. Walaupun demikian, masih terdapat disparitas antar provinsi yang variasinya cukup besar. Selain adanya kesenjangan, juga ditemukan ibu hamil yang tidak menerima pelayanan dimana seharusnya diberikan pada saat kontak dengan tenaga kesehatan (Kemenkes R.I, 2019).

Berdasarkan data yang diperoleh Dinas Kesehatan dari 5 Puskesmas kelas ibu hamil yang terbentuk hanya 59 pos dengan jumlah ibu hamil yang mengikuti kelas ibu hamil sebanyak 2.450 orang dari 3.750 ibu hamil keseluruhan. Angka kematian ibu di Kota Langsa dari tahun 2016 sebanyak 3 ibu dan terjadi peningkatan di tahun 2017 sebanyak 5 ibu terus meningkat lagi ditahun 2018 sebanyak 9 ibu (Dinas Kesehatan Kota Langsa 2019). Sedangkan data dari Puskesmas Langsa Baro (2018) diketahui hanya 247 ibu hamil yang mengikuti kelas ibu hamil dari sasaran ibu hamil 1.095 orang. AKB sebanyak 5 kasus, AKN sebanyak 1 Kasus dan bayi lahir mati 3 kasus. Data angka kesakitan pada ibu tahun 2018 di dunia 


\section{JKM (Jurnal Kebidanan Malahayati),Vol 7,No.4.Oktober 2021, ISSN (Print) 2476-8944 ISSN (Online) 2579-762X, Hal 731-737}

mencapai $8 \%$ dengan penyakit DM, Hipertensi dan Kelainan metabolik. Di Indonesia morbiditas yang terjadi pada ibu hamil, bersalin dan nifas mencapai 6 ibu dari 100.000 ibu hamil, bersalin dan nifas dengan penyakit hipertensi dan asma. Sedangkan di Aceh angka morbiditas pada ibu diketahui sebanyak 9 ibu dari 100.000 ibu. Untuk angka morbiditas ibu hamil, bersalin dan nifas di Kota Langsa mencapai angka 6 dari 100.000 ibu dan di Puskesmas Langsa Baro sendiri berada pada angka 5 dari 100.000 ibu (Dinkes Aceh 2019).

Upaya untuk meningkatkan pengetahuan masyarakat tentang kesehatan ibu dan anak tersebut, maka dapat dilakukan suatu penyuluhan kesehatan ibu dan anak. Salah satu upaya untuk dapat memberikan pengetahuan yanag cukup kepada ibu hamil dan keluarga melalui kelas ibu hamil. Kelas ibu hamil merupakan kegiatan pemberdayaan masyarakat melalui sarana belajar kelompok tentang kesehatan ibu hamil dengan memanfaatkan buku KIA. Dengan kegiatan kelas ibu hamil ini suami dan keluarga akan dilibatkan sehingga dapat memahami kondisi ibu hamil sampai dengan melahirkan dan merawat bayi (Laras P, 2015). Penerapan kelas ibu hamil diharapkan dapat meningkatkan aksesibilitas ibu hamil terhadap pelayanan kesehatan ibu dan anak yang berkualitas sehingga dapat menjadi salah satu upaya dalam penurunan AKI dan AKB. Pengaruh yang terjadi dari pemberian materi kelas ibu hamil yang disampaikan secara komprehensif dan berkesinambungan diharapkan terjadi peningkatan pengetahuan, perubahan sikap dan perilaku ibu hamil dalam perawatan kehamilan, persalinan, dan nifas (Departemen Kesehatan RI 2015).

Selama ini dalam memberikan pendidikan kesehatan, yang sering digunakan adalah metode tatap muka atau ceramah. Metode ini memang lebih mudah dilakukan, akan tetapi kurang efektif. terhadap pemahaman masyarakat terhadap penyakit yang mematikan. Menggunakan metode ini adalah karena pertimbangan adanyaketerbatasan waktu, biaya, tenaga dan sarana (Harahap, 2016). Pada survei awal yang dilakukan pada 11 ibu hamil yang berkunjung ke Posyandu Desa Geudubang Jawa didapatkan hasil hanya 3 orang $(20 \%)$ ibu hamil yang mampu menjawab pertanyaan meliputi berapa kali idealnya seorang ibu hamil memeriksakan kehamilannya, persiapan persalinan harus terprogram melalui persiapan persalina, perawatan post partum dimulai sejak 1 jam setelah lahirnya plasenta dampai dengan 6 minggu (42 hari) setelah itu, sedangkan 8 orang ibu hamil tidak mampu menjawab pertanyaan dengan benar. Dari sikap 11 ibu hamil yang diwawancara diperoleh hasil 8 orang $(70 \%)$ menunjukkan sikap tidak penting memeriksakan kehamilan ke tenaga kesehatan walaupun penting bersalin di tenaga kesehatan dan 3 orang $(30 \%)$ menunjukkan respon baik bahwa memeriksakan kehamilan harus sejak awal ke tenaga kesehatan. Selama ini kelas ibu hamil dilakukan dengan metode konversional yaitu metode ceramah dengan media lembar balik. Mengingat hal tersebut, perlu upaya alternative dalam memperbaiki pengetahuan dan sikap ibu tertang perawatan kehamilan, persalinan dan nifas. Tujuan penelitian yaitu Untuk mengetahui pengaruh metode pembelajaran multimedia dalam kelas ibu hamil terhadap pengetahuan dan sikap ibu tentang perawatan selama kehamilan, persalinan dan nifas di wilayah kerja Puskesmas Langsa Baro.

\section{METODE PENELITIAN}

Jenis Penelitian ini merupakan Quasiexsperimental. Desain Penelitian menggunakan pendekatan pretest-postest with two group.Kelompok kontrol kelas ibu hamil menggunakan metode pembelajaran konversional, sedangkan kelompok perlakuan menggunkan metode pembelajarn multimedia. Setiap kelompok dilakukan pretest dan posttes menggunakan kuesioner untuk mengetahu pengetahuan dan sikap ibu tentang perawatan kelamilan, persalinan dan nifas pada ibu hamil. Penelitian dilaksanakan pada tanggal 7 sampai 25 Mei 2019. Lokasi penelitian dilakukan di wilayah kerja Puskesmas Langsa Baro Kota Langsa. Pertemuan kelas ibu hamil sebanyak 3 kali/ minggu secara berturut-turut. Sampel penelitian berjumlah 34 ibu hamil. Teknik pengambilan sampel yaitu purposive sampling, yaitu penentuan sampel dengan pertimbangan tertentu berdasarkan kriteria inklusi yang telah ditentukan. Kriteria inklusi adalah ibu hamil trimester III, primigravida, kehamilan normal, ibu hamil yang berada di wilayah kerja Puskesmas Langsa Baro dan bersedia menjadi responden. Instrumen yang digunakan berupa kuesioner. Analisa data yaitu uji $t$-dependent. Penelitian ini sudah mendapatkan persetujuan dari komisi etik penelitian Kesehatan Fakultas Keperawatan USU dengan nomor: 2275/N/SP/2019.

\section{HASIL DAN PEMBAHASAN \\ Karakteristik Responden}

Berdasarkan tabel 1. di bawah dapat dilihat bahwa mayoritas usia responden adalah 20-25 tahun sebanyak 19 responden, mayoritas pendidikan responden adalah SMA yaitu sebanyak 20 ibu dan mayoritas status pekerjaan responden adalah tidak berkerja yaitu sebanyak $21 \mathrm{ibu}$. 
Tabel 1.

Distribusi Frekuensi umur, pendidikan dan pekerjaan Ibu Hamil di wilayah kerja Puskesmas Langsa Baro

\begin{tabular}{|c|c|c|c|c|c|c|}
\hline \multirow{3}{*}{ Kategori } & \multicolumn{6}{|c|}{ Kelompok Responden } \\
\hline & \multicolumn{2}{|c|}{ Perlakuan } & \multicolumn{2}{|c|}{ Kontrol } & \multicolumn{2}{|c|}{ Total } \\
\hline & $\mathbf{n}$ & $\%$ & $\mathbf{n}$ & $\%$ & $\mathbf{N}$ & $\%$ \\
\hline \multicolumn{7}{|l|}{ Usia (Tahun) } \\
\hline 20-25 tahun & 9 & 52,9 & 10 & 58,8 & 19 & 55,9 \\
\hline >25 Tahun & 8 & 47,1 & 7 & 41,2 & 15 & 44,1 \\
\hline \multicolumn{7}{|l|}{ Pendidikan } \\
\hline SMP & 3 & 17,6 & 3 & 17,6 & 6 & 27,6 \\
\hline SMA & 9 & 52,9 & 11 & 64,7 & 20 & 58,8 \\
\hline Diploma & 2 & 11,8 & 1 & 5,9 & 3 & 8,8 \\
\hline Sarjana & 3 & 17,6 & 2 & 11,8 & 5 & 2,9 \\
\hline \multicolumn{7}{|l|}{ Status Pekerjaan } \\
\hline Berkerja & 6 & 35,3 & 7 & 41,2 & 13 & 38,24 \\
\hline Tidak Berkerja & 11 & 64,7 & 10 & 58,8 & 21 & 61,76 \\
\hline Total & 17 & & 17 & & 34 & 100 \\
\hline
\end{tabular}

Perbedaan Pengetahuan dan Sikap Sebelum dan Sesudah Diberikan Perlakuan

Hasil dependent $T$ testpengeahuan dan sikap pre-test dan post-test berikut ini:

Berdasarkan tabel di atas maka dapat diketahui hasil uji statistik menunjukkan nilai $P$ value pengetahuan kelompok perlakuan adalah 0,000 yang berarti $P$ value $<$ dari nilai a $(0,000<0,05)$, nilai $P$ value sikap kelompok perlakuan perlakuan adalah 0,000 yang berarti $P$ value $<$ dari nilai $a$ $(0,000<0,05)$.

Tabel 2

Uji Dependen $T$ test Pengetahuan dan Sikap (pre-test dan post-test) Antar Kelompok

\begin{tabular}{llccccc}
\hline \multicolumn{1}{c}{ Kelompok } & Variabel & Mean & SD & SE & P value & $\mathbf{n}$ \\
\hline $\begin{array}{l}\text { Pengetahuan } \\
\text { Perlakuan }\end{array}$ & Pre-test & 13,4 & 3,001 & 0,728 & & \\
\multirow{3}{*}{ Kontrol } & Post-test & 18,88 & 1,996 & 0,484 & 0,000 & 17 \\
& Pre-test & 14 & 2,958 & 0,717 & 0,242 & 17 \\
Sikap & Post-test & 15 & 3,317 & 0,804 & & \\
Perlakuan & & & & & & \\
\multirow{2}{*}{ Kontrol } & Pre-test & 42,18 & 12,709 & 3,082 & 0,000 & 17 \\
& Post-test & 51,88 & 8,609 & 2,008 & & \\
& Pre-test & 43,18 & 8,904 & 2,16 & 0,631 & 17 \\
\hline
\end{tabular}

Perbandingan Pengetahuan dan Sikap Antar Kelompok

Hasil Independent $T$ testpengeahuan dan sikap pre-test dan post-test dapa disajikan sebagai berikut ini:

Tabel 5.

Perbandingan Pengetahuan dan Sikap ibu hamil Antar Kelompok

\begin{tabular}{|c|c|c|c|c|c|c|c|}
\hline \multirow{2}{*}{ Variabel } & \multirow{2}{*}{$t_{\text {hitung }}$} & \multirow{2}{*}{$t_{\text {tabel }}$} & \multirow{2}{*}{$d f$} & \multicolumn{2}{|c|}{ Rerata \pm SD } & \multirow{2}{*}{ Rerata \pm SE } & \multirow{2}{*}{$\mathbf{P}$} \\
\hline & & & & Perlakuan & Kontrol & & \\
\hline Pengetahuan & 4,137 & 2,037 & 32 & $18,88 \pm 1.996$ & $15,00 \pm 3,317$ & $3,882 \pm 0,939$ & 0,000 \\
\hline Sikap & 2,528 & 2,037 & 32 & $51,88 \pm 8,609$ & $10,184 \pm 2,470$ & $8,176 \pm 3,234$ & 0,017 \\
\hline
\end{tabular}




\section{JKM (Jurnal Kebidanan Malahayati),Vol 7,No.4.Oktober 2021, ISSN (Print) 2476-8944 ISSN (Online) 2579-762X, Hal 731-737}

Berdasarkan tabel di atas dapat diketahui bahwa untuk variabel pengetahuan diperoleh nilai $p=0,000$ yang bermakna bahwa terdapat perbedaan yang signifikan antara kedua kelompok responden dan variabel sikap diperoleh hasil $p=$ 0,017 yang bermakna terdapat perbedaan signifikan antar kelompok perlakuan dan kontrol. Dengan demikian dalam penelitian ini $\mathrm{H}_{0}$ ditolak dan $\mathrm{H}_{a}$ diterima. Maka artinya ada perbedaan pengaruh metode belajar konversional dengan metode multimedia dalam kelas ibu hamil terhadap pengetahuan dan sikap ibu tentang perawatan kehamilan, persalinan dan nifas di wilayah kerja Puskesmas Langsa Baro Kota Langsa setelah mengikuti dan sebelum mengikuti kelas ibu hamil.

\section{PEMBAHASAN}

Hasil penelitian ini menunjukkan (tabel 1) bahwa mayoritas usia responden adalah 20-25 tahun sebanyak 19 responden, mayoritas pendidikan responden adalah SMA yaitu sebanyak 20 ibu dan mayoritas status pekerjaan responden adalah tidak berkerja yaitu sebanyak 21 ibu. Hasil penelitian ini sesuai dengan penelitian yang dilakukan oleh Merdhika,dkk (2014) menyimpulkan pengetahuan ibu dipengaruhi oleh umur ibu, pendidikan dan pekerjaan ibu. Pengetahuan sangat erat hubungannya dengan pendidikan, dimana diharapkan bahwa dengan pendidikan yang tinggi maka orang tersebut akan semakin luas pula pengetahuannya. Akan tetapi perlu ditekankan bukan berarti seseorang yang berpendidikan rendah mutlak berpengatahuan rendah pula. Hal ini mengingat bahwa peningkatan pengetahuan tidak selalu diperoleh dari pendidikan formal saja tetapi juga dapat diperoleh melalui pendidikan non formal juga (Wawan and Dewi 2011).

Hasil penelitian Cici (2019), bahwa makin tinggi tingkat pendidikan seseorang maka akan semakin mudah menerima informasi sehingga makin banyak pula pengetahuan yang dimiliki. Umur juga dapat mempengaruhi pengetahuan ibu karena semakin matang usia seseorang maka akan semakin banyak pula pengalamannya. Selain itu umur yang matang umumnya akan memiliki pola tangkap dan daya pikir yang baik sehingga pengetahuan yang dimilikinya juga akan semakin membaik. Pekerjaan juga bisa jadi salah satu faktor yang mempengaruhi pola pikir seseorang. Berdasarkan hasil analisis data (tabel 4.2) di atas dapat dinyatakan bahwa pengetahuan responden sebelum dilakukan kelas ibu hamil yaitu mayoritas responden memiliki pengetahuan kurang yaitu sebanyak 9 responden $(52,9 \%)$, sedangkan pengetahuan responden pada kelompok kontrol mayoritas berpengetahuan cukup yaitu sebanyak 10 responden (58,8\%). Pengetahuan responden sesudah mengikuti kelas ibu hamil yaitu pada kelompok perlakuan mayoritas responden memiliki pengetahuan cukup yaitu sebanyak 11 responden $(64,7 \%)$ sedangkan pengetahuan responden pada kelompok kontrol mayoritas berpengetahuan cukup yaitu sebanyak 7 responden $(41,2 \%)$.

Metode pembelajaran kelas ibu hamil mempunyai pengaruh dalam meningkatkan pengetahuan ibu hamil tentang perawatan kehamilan, persalinan, nifas dan BBL dibuktikan dengan terdapat perbedaan pengetahuan sebelum dan sesudah mengikuti kelas ibu hamil dengan ratarata sebelum mengikuti 13,4 (kurang) dan setelah mengikuti rata-rata 18,88 (cukup), yang berarti pengetahuan ibu dapat dipengaruhi oleh metode pembelajaran kelas ibu hamil. Kelas ibu hamil ini merupakan sarana untuk belajar bersama tentang kesehatan bagi ibu hamil, persalinan dan nifas yang dilakukan dalam tatap muka dalam kelompok yang bertujuan untuk meningkatkan pengetahuan dan ketrampilan ibu-ibu mengenai perawatan kehamilan, persalinan dan nifas, mitos, penyakit menular dan akte kelahiran.

Asumsi peneliti metode kelas ibu hamil sangat mempengaruhi pengetahuan ibu tentang teori yang diberikan. Metode yang tepat akan memudahkan ibu untuk menerima informasi yang diberikan sehingga informasi tersebut dapat ibu serap dan diterapkan. Dengan metode multimedia ibu lebih mudah memahami apa yang diajarkan selain itu multimedia juga mampu membuat suasan belajar yang lebih kondusif, ibu menjadi lebih ingin tahu dan mudah menerima. Dengan begitu maka akan menambah wawasan dan pengetahuan ibu dari yang sebelum mengikuti kelas ibu hamil dibandingkan dengan sesudah mengikuti kelas ibu tentang perawatan kehamilan, persalianan dan nifas yang akan dilalui ibu. Dibuktikan dengan adanya perbedaan tingkat pengetahuan ibu sebelum dan sesudah diberikan perlakuan. Pada kelompok kontrol ibu akan merasa lebih mudah bosan dengan penyampaian yang diberikan sehingga informasi tidak mampu ibu terima, sementara pada kelompok perlakuan yang menggunakan multimedia akan mengundang suasana yang lebih kondusif sehingga informasi yang disampaikan akan mudah ibu terima.

Berdasarkan hasil analisis data (table 2) di atas dapat dinyatakan bahwa pada kelompok perlakuan mayoritas responden bersikap tidak mendukung yaitu sebanyak 14 ibu $(82,4 \%)$ ibu dan pada kelompok kontrol mayoritas bersikap tidak mendukung yaitu sebanyak 14 responden $(82,4 \%)$. 


\section{Elman Fitriani, Dewita Dewita}

Sikap responden sesudah mengikuti kelas ibu hamil pada kelompok perlakuan mayoritas responden bersikap mendukung yaitu sebanyak 12 ibu $(70,6 \%)$ ibu dan pada kelompok kontrol mayoritas bersikap tidak mendukung yaitu sebanyak 12 responden (70,6\%). Hasil uji stistik yang disajikan dalam (tabel 4) menunjukkan nilai $P$ value sikap adalah 0,000 yang berarti $P$ value $<a(0,000<0,05)$ maka dapat disimpulkan bahwa ada pengaruh metode pembelajaran multimedia dalam kelas ibu hamil terhadap sikap ibu tentang perawatan kehamilan, persalinan dan nifas di wilayah kerja Puskesmas Langsa Baro.

Metode pembelajaran kelas ibu hamil dapat mempengaruhi sikap ibu hamil dalam melakukan perawatan kehamilan, persalinan dan nifas dibuktikan dengan terdapat perbedaan sikap sebelum dan sesudah mengikuti kelas ibu hamil dengan rerata sebelum mengikuti pembelajaran 42,18\% (Tidak mendukung) dan sesudah mengikuti pembelajaran $51,88 \%$ (mendukung), yang berarti sikap ibu dipengaruhi oleh metode pembelajaran kelas ibu hamil. Hasil penelitian ini sesuai dengan hasil penelitian yang dilakukan Laras P ( 2015), yaitu adanya pengaruh antara inensifikasi kelas ibu hamil terhadap pengetahuan $(0,000)$ dan sikap $(0,021)$ dalam pencegahan KEK. Hasil penelitian lain menunjukkan bahwa kelas ibu hamil efektif untuk memperbaiki sikap dan kunjungan antenatal care (ANC). Faktor yang memegang peranan penting dalam perubahan sikap responden pada penelitian ini adalah reaksi/respon terhadap kelas ibu hamil, selain karena keterlibatan faktor perasaan dan emosi (Pattipeilohy 2017).

Asumsi penulis menyimpulkan metode pembelajaran kelas ibu hamil dapat mempengaruhi sikap ibu dikarenakan seiring meningkatnya pengetahuan dan wawasan ibu tentang pentingnya perawatan kehamilan, persalinan dan nifas sehingga ibu dapat akan memiliki perspektif yang lebih baik. Perbedaan sikap pada kelompok kontrol dan kelompok perlakuan terjadi karena padakelompok kontrol ibu akan merasa lebih mudah bosan dengan penyampaian yang diberikan sehingga informasi tidak mampu ibu terima, sementara pada kelompok perlakuan yang menggunakan multimedia akan mengundang suasana yang lebih kondusif sehingga informasi yang disampaikan akan mudah ibu terima. Jika ibu tidak memahami pesan yang disampaikan maka ibu tidak akan merespon atau mengganggap perawatan kehamilan, persalinan dan nifas serta BBL tidak terlalu pening sehingga akan mempengaruhi sikap ibu pula.

\section{SIMPULAN}

Hasil penelitian menunjukkan adanya pengaruh metode pembelajaran multimedia kelas ibu hamil terhadap pengetahuan dan sikap ibu tentang perawatan kehamilan, persalinan dan nifas di wialayah kerja Puskesmas Langsa Baro.

\section{SARAN}

Bagi pelayanan kesehatan hendak nya dapat menerapkan kelas ibu hamil dengan metode pembelajaran multimedia.

\section{DAFTAR PUSTAKA}

Cici, Erianty. 2019. "Hubungan Pengetahuan Dengan Sikap Lansia Dalam Memenuhi Personal Hygiene Di Unit Pelaksana Teknis Puskesmas Tanjung Beringin Serdang Bedagai." : 101.

Depatemen Kesehatan RI. 2015. Journal of Neurogastroenterology and Motility Pedoman Pelaksanaan Kelas Ibu Hamil. https://libportal.jica.go.jp/library/Archive/Indo nesia/232i.pdf.

Dinas Kesehatan Kota Langsa. 2019. Laporan Kasus Tahun 2018.

Dinkes Aceh, Dinas Kesehatan. 2019. "Profil Kesehatan Aceh." Dk 53(9): 1689-99.

Harahap, Desy Maisyarah. 2016. "Pengaruh Kelas Ibu Hamil Terhadap Pengetahuan Dan Sikap Ibu Tentang Perawatan Selama Kehamilan, Persalinan Dan Nifas Di Wilayah Kerja Puskesmas Karang Rejo Kabupaten Langkat." Universitas Sumatera Utara (X): 15.

Laras Prastiyawati. 2015. Skripsi Universitas Negeri Semarang "Intensifikasi Kelas lbu Hamil Terhadap Pengetahuan Dan Sikap Pencegahan Kurang Energi Kronis Di Desa Purbosono Kecamatan Kertek Kabupaten Wonosobo." http://lib.unnes.ac.id/23133/.

Merdhika, Widha Ayu Rima, Mardji, and Mazarina Devi. 2014. "Pengaruh Penyuluhan ASI Eksklusif Terhadap Pengetahuan lbu Tentang ASI Eksklusif Dan Sikap Ibu Menyusui Di Kecamatan Kanigoro Kabupaten Blitar." Teknologi Dan Kejuruan 37(1): 65-72.

Pattipeilohy, Maria Yosefa. 2017. "Faktor-Faktor Yang Mempengaruhi Perilaku Ibu Terhadap Ketepatan Kunjungan Antenatal Care Di Puskesmas Rekas Kabupaten Manggarai Barat Nusa Tenggara Timur Tahun 2017." Journal of Chemical Information and Modeling 53(9): 1689-99. 
JKM (Jurnal Kebidanan Malahayati),Vol 7,No.4.Oktober 2021,

ISSN (Print) 2476-8944 ISSN (Online) 2579-762X, Hal 731-737

http://eprints.poltekkesjogja.ac.id/1721/1/skri psi full.pdf.

R.I, Kementerian Kesehatan. 2019. Short Textbook of Preventive and Social Medicine Profil Kesehatan Indonesia 2018. ed. Boga Hardana. Jakarta: KEMKES RU.

Wawan, A, and M Dewi. 2011. Teori \& Pengukuran
Pengetahuan, Sikap Dan Perilaku Manusia. Yogyakarta: Nuha Medika.

World Health Organization. 2017. World Health Statistic 2017: Monitoring Health for the SDGs.

https://apps.who.int/iris/handle/10665/25533 6. 